\title{
Cultivating Brand Awareness of Korean Cosmetics Innisfree in Indonesia Via E-WOM as the Eco-Friendly
}

\author{
S Ariella ${ }^{1}, U_{\text {Yunus }}{ }^{2,3}$ \\ ${ }^{1}$ Master of Strategic Marketing Communication, Universitas Bina Nusantara, Jakarta, \\ Indonesia \\ ${ }^{2}$ Research Interest Group-Cross Cultural Communication, Universitas Bina Nusantara, Jakarta, \\ Indonesia \\ ${ }^{3}$ Marketing Communication Program, Communication Department, Faculty of Economics \& \\ Communication, Universitas Bina Nusantara, Jakarta, Indonesia \\ ${ }^{1}$ sophia.ariella@binus.ac.id
}

\begin{abstract}
In the digital age, consumers actively search for information on a specific product and are predicted to buy one with a specific brand by the information distribution, the electronic Words of Mouth (e-WOM) and the brand awareness. The purpose of this study is to analyze how to develop the brand awareness of Innisfree, a Korean beauty product brand, as an eco-friendly product through eWOM. This study used a qualitative approach by evaluating various things that occurred in their natural environment, to understand or interpret a phenomenon based on what people think of the research subject. The result of this study indicated that Innisfree brand awareness in Indonesian women has been in accordance with the company's target, as shown by the increasing number of transactions and visitors to Innisfree outlets in four locations. The awareness process of Innisfree brand as eco-friendly products through e-WOM has been successfully created, shown by positive comments from Innisfree facebook follower, in the Indonesian web and market places.
\end{abstract}

Keywords: Korean Cosmetics, Innisfree, E-WOM

\section{INTRODUCTION}

People are most likely motivated to buy a product with a specific brand because of the traditional Word of Mouth (WOM) information distribution, such as through family and colleagues. In the digital age, WOM has expanded into e-WOM (electronic Word of Mouth), the way of spreading messages on personal social media. A study proved that the culture may influence the social media in the decision to purchase a product social media and this is different from the traditional WOM that influences through only family or friends [1].

In branding activities, Word of Mouth (WOM) is defined as a process of exchanging messages between consumers because most of the time they depend on others for help in purchasing decisions, especially for products with high financial or psychological risks. Some studies show empirically that WOM is more persuasive than traditional media channels [2]. Electronic-Word of Mouth (e-WOM) has a significant effect as well on purchase intention in 
terms of reviews. The two most effective functions mentioned in the review are the functions of the ego defense and the function of knowledge [3].

Currently, Korea is well-known for its drama, K-Pop music with beautiful and handsome talents, especially the ones with delicate skin. Korea has successfully managed its image brand and has been considered successful in deploying soft power culture. Through its popular culture, Korea has earned its own recognition, respect, and place in the international community. These conditions have a good impact on the products they spread throughout the world including Indonesia, and that includes cosmetics products. This success is seen from the sales turnover with amazing value of Rupiah in less than a year. Figure 1 tells the success of this product.

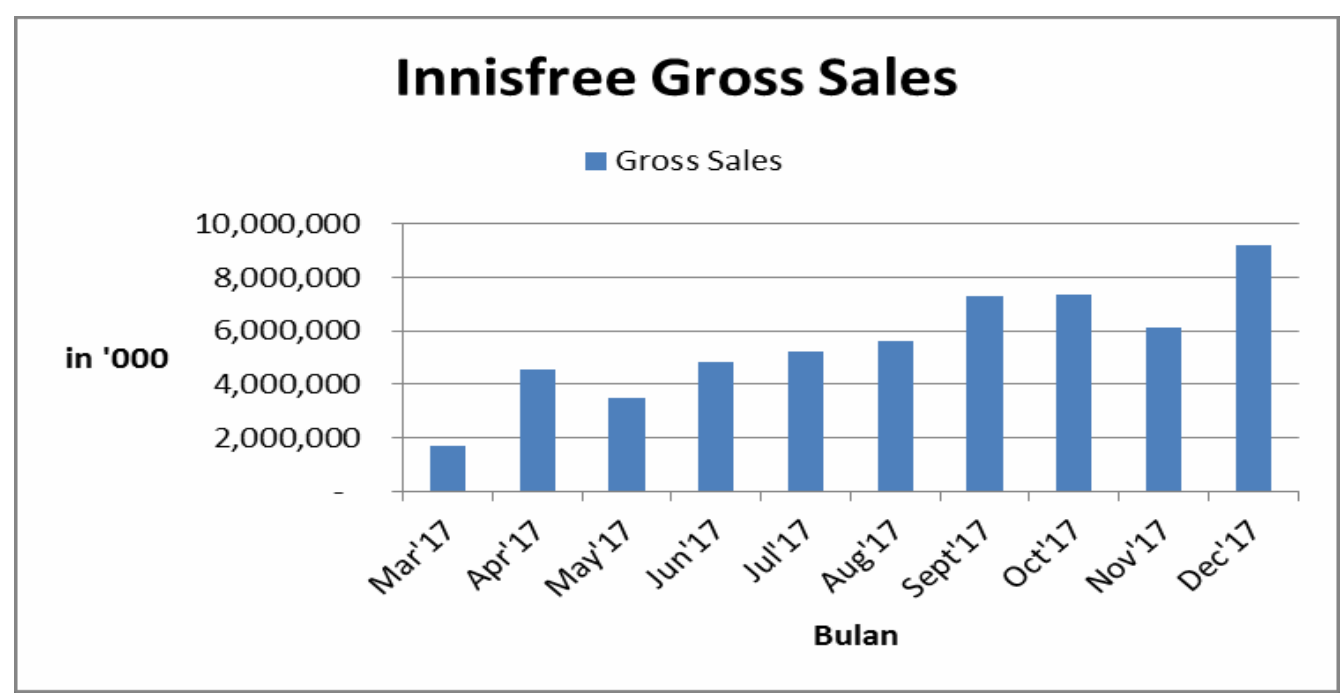

Figure 1. Innisfree's gross sales in Indonesia on 2017 (in thousand Rupiah).

Innisfree appointed PT Pramodha as its official brand consignment in Indonesia. According to PT Pramodha's internal data, until the end of 2017, Innisfree has opened 3 outlets in Indonesia, in Central Park Mall and Mall Senayan City, Jakarta, and in Paris Van Java, Bandung. Sales graph for approximately 9 months from March to December 2017 shows an increase in sales. Initially reached Rp2,000,000,000 from its first outlet at Central Park Mall, Innisfree managed to reach approximately Rp10,000,000,000 from its three outlets throughout Indonesia. Innisfree then opened its 4th store in Summarecon Mall Serpong in early 2018.

The above successes are predicted because of Korean's powerful brand and culture as well as its eco-friendly product campaign in social media. Although not many customers are aware of the potential environmental damage caused by modern products, we realize that the results of green marketing will not give impacts in the short term [4].

Based on the background mentioned above, this research focuses on how to raise brand awareness of Korean cosmetics products Innisfree as an eco-friendly product brand through eWOM. Two questions appear in the regard of that focus: How good is Innisfree's brand awareness to Indonesian women? How does Innisfree manage e-WOM for its brand awareness in social media? 


\section{LITERATURE REVIEW}

In 2014 Goodricha\&Mooij conducted a research using a cultural dimension to compare the use of social media and other sources of information for consumers' decision making in 50 countries. The results show that, with different cultures, WOM on social media influences purchases differently than traditional WOM through family or friends [1].

Macdonald \& Sharp in 2000 mentioned that brand awareness was proven to influence consumers in making purchase decisions of a famous brand compared to 3 other brands. This brand awareness technique is a dominant marketing tactic for consumers who are less experienced in determining purchase decisions [5].

The expertise and credibility of e-WOM sources may have an impact on consumer purchase decisions with moderating role of product type, in this case, trust. Homophily with friends is considered an important factor that generates mutual trust because of strong ties [6].

\subsection{Brand Awareness}

Brand awareness is the capacity of consumers to recognize or remember a brand, and there is a linkage between the brand and the product class. There are 4 levels of brand awareness: unaware of brand, brand recognition, brand recall, and top of mind [7]. Through brand awareness, the consumers are actively seeking information to help determine purchase options [5]. Signs of awareness are: the consumers remember the brands easily and the time when the consumers buy products. That means the product has a higher brand awareness in society [8]. Brand awareness is the ability of a consumer to remember that a particular brand exists [9]"

\subsection{Electronic Word of Mouth.}

E-WOM exists because of the development of today's media, that is a digital world. In the past, brands relied on traditional WOM. "Power of Word of Mouth (WOM), whether face to face or online, can never be underestimated. Whether it relates to the adoption of the new product or selection between alternative brands or just watching a television show; the WOM (word of mouth) plays a significant role in the consumer decision-making process" [6] Along with the development of media convergence that is the social media, e-WOM was born. How e-WOM is distributed[10]

- Posted Review, including consumer opinions published on the Internet by sellers, sites that provide space for consumer opinions or consumers that publish their opinions on their own blogs.

- Mailbags, including comments from consumers or readers and feedback published on the organization'swebsite.

- Discussion Forum, includes bulletin boards, and ongoing discussions published on a particulartopic.

- Electronic Mailing List, including consumer opinions sent to certain e-mailmembers.

- Personal email, including emails sent from one person to another or a specificgroup.

- Chat rooms, including the conversation of a group of people on the internet on a particular topic.

- Instant Messaging, a real-time conversation between one person toanother.

The use of information sources that influence online purchase decisions varies widely by culture, for example, people put more trust in opinion based on homophily, compared to 
individual opinions in social media. "Interestingly culture affects the influence of traditional WOM through family or friends"[1].

\section{METHODS}

This study uses a qualitative approach, that is a research involving many methods in data collection, as a way to study the problem. The use of many methods is called triangulation aimed for researchers to gain a comprehensive understanding of the phenomenon studied. In accordance with its epistemological principle, qualitative researchers commonly examine the things within their natural environment, seek to understand or interpret, phenomena based on the meanings that people give to the subject matter [11]. Conventional qualitative methods tend to be associated with the desire of researchers to examine meanings, contexts, and a holistic approach to phenomena [12].

Testing of data validity is done by triangulation technique--testing by having other sources as a comparison to the research result and getting a more convincing statement. This test uses interviews with informants and is supported by the literature. The expectation is that the results can be used as a comparison of existing research results, that is, through observation in social media as Innisfree brand e-WOM.

This research was conducted for four months from January to April 2018, as it was accompanied by preliminary research through observation of consumer behavior at Central Park and Senayan City outlets, social media observation and interviews to relevant informants and are validated to the expert, which is, in this study, a beauty influencer. The criteria of informants are Innisfree loyal customerswho shop at least once a month, and Platinum Innisfree member card holder (with a minimum purchase of $\mathrm{Rp} 1,250,000$ annually). Meanwhile, the criteria of influencer is a female beauty blogger who has more than 50,000 followers inInstagram.

\section{RESULT ANDDISCUSSION}

\subsection{Brand Awareness Innisfree Of Indonesian Women}

In building brand awareness, Innisfree has conducted eco-friendly campaigns such as printing handkerchiefs to replace tissues, recycling 4,577,486 bottles as recorded up to 2017 . The campaign continues with the theme of "Clean Jeju" campaign. This is an action of Educational programs - public relations to build awareness of the environment and recycling [4].

The increase in sales of foreign cosmetics products which have just entered the market in Indonesia is quite significant. This is because some people are already aware of the Innisfree brand. The role of South Korean dramas is considered to have an effect on the consumption behavior of Indonesians.

According to its social culture, Indonesia is an attractive market for cosmetic products and many cosmetic brands keep entering the Indonesian market. Besides Korea, China, Japan and even England, America and France have begun to dominate the Indonesian market. There is a change of trend in Indonesia in the world of beauty, for the Indonesian people are aware to take care of their skin, not only for decorative purpose but also for having good-looking and healthy skin. This change occurs, thanks to the role of South Korean drama. Indonesians have seen that Koreans have a healthy and beautiful skin, so they want to have that type of skin as well [13] 
Up to now, the cosmetics business in Indonesia has become a promising business. These developments encourage the growth of the local and international cosmetics industry. Data from the Ministry of Industry shows that the growth of the cosmetics industry has reached $20 \%$. According to Airlangga Hartanto, based on the data of the Ministry of Industry, the sales value of the soap cosmetics industry and cleaning materials in 2017 reached Rp19 trillion. The sales raised by 11.99 percent compared to the ones in 2016. The average export growth of cosmetic products in the past five years reached 3.56 [14].

Innisfree brand awareness of Indonesian women is seen from the customer visitors to Innisfree's four outlets with fantastic figures as shown below:

Table 1. Summary Sales Innisfree 20-27 April 2018.

\begin{tabular}{lllllc}
\hline & $\begin{array}{c}\text { Senayan } \\
\text { City }\end{array}$ & $\begin{array}{c}\text { Central } \\
\text { Park }\end{array}$ & $\begin{array}{c}\text { Summarecon } \\
\text { Mall } \\
\text { Serpong }\end{array}$ & $\begin{array}{l}\text { Paris Van } \\
\text { Java }\end{array}$ & TOTAL \\
\cline { 1 - 6 } Total Sales (in Rupiah) & $605,443,000$ & $\underline{721,385,000}$ & $\underline{376,474,000}$ & $\underline{450,415,000}$ & $\underline{2,153,717,000}$ \\
\cline { 2 - 7 } Total Items Sold (in pcs) & 8,328 & 10,346 & 7,643 & 7,583 & 33,900 \\
\hline Total Customers & 2,198 & 2,865 & 1,817 & 2,025 & 8,905 \\
\hline
\end{tabular}

Within one week, there were 8,905 customers who made transactions at Innisfree outlets, not to mention, the online transactions in social media by the resellers. Through social media, brand awareness in Indonesia is seen to be very high. Innisfree's Instagram has 132k followers, Facebook got4.9 out of 5 stars based on 169 reviews. 121,532 people like the page and 122,235 follow Innisfree's Facebook account. Here are examples of product reviews published in social media related to the strength of the brand image. See Figure 2 which states that Innisfree products are highly recommended, the store is good, and the service is good:

Innisfree
Indonesia $\odot$
@innisfreeindonesia
Beranda
Kiriman
Ulasan
Video
Foto
Tentang
Komunitas
Promo

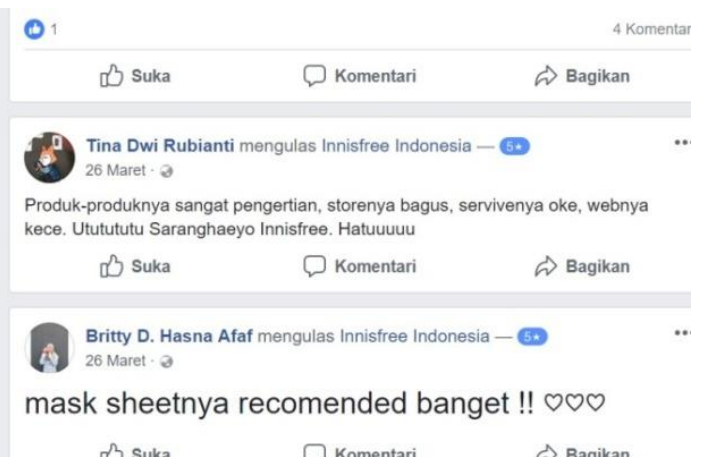

Figure 2. Brand Awareness on Innisfree Products

An informant explained that she initially knew about Innisfree as a Korean beauty product because of a number of famous Korean artists who became Innisfree's ambassadors in social media, such as actor Lee Min Ho who has an Instagram account with $1.8 \mathrm{~m}$ followers, and SNSD's Yoona who has an Instagram account with $9 \mathrm{~m}$ followers. The brand awareness of Innisfree brand is supported by the rampant posts and reviews of beauty influencers in 
Instagram. The informant mentioned that friends' recommendations through social media about Innisfree products cause the motivation to buy.

Innisfree brand is positively mentioned in social media. Thus, the Innisfree's brand awareness targeting Indonesian women is in line with the company's objective to push sales transactions.

\subsection{Managing Brand Through E-WOM as Eco-Friendly Product}

The Korean beauty industry has a worldwide popularity due to the pop culture created so as to have the accessibility of products in the world market. Marie Claire, beauty and fashion magazine, has named Korea a new skin care superpower, considering Korea has been innovating for about 12 years in the global skin care industry. Natural ingredients have been fueling interest in Korean beauty products. Korean cosmetic brands tend to avoid chemicals and combine natural elements such as green tea, bamboo sap, and bee venom, instead. Even the face mask uses herbs and natural ingredients [15].

Innisfree from Korea is associated with eco-friendly products although the brand just entered the Indonesian market in 2017. Innisfree brand concept is also associated with Jeju Island, famous for its natural beauty producer. Innisfree becomes a brand that utilizes the natural benefits of Jeju Island, an island with natural beauty when living side by side with nature and maintaining its beauty.

Innisfree, launched in 2000, was a pioneer brand that focuses on cosmetics with natural ingredients and has been certified by ECOCERT organization which is a worldwide certification body that examines the company's products as ecologically responsible, environmentally friendly and complies with global standards in the organic sector.

Innisfree's brand awareness in Indonesia has been appropriately processed because of social media. The role of the makeup artist and the influencer in the social media has strengthened Innisfree's position as an eco-friendly product. Through social media, Innisfree's e-WOM was created as the consumers volunteered to discuss product reviews. Discussions on social media about Innisfree have occurred, mentioning the advantages, disadvantages, where to get the product, even discussed the price, without face toface.

The informant explained that the first time she knew Innisfree as an eco-friendly product was from the posts and reviews of beauty influencers on Instagram about the product, which was still new in Indonesia at that time. On the first day of Innisfree store's opening, many influencers covered their shopping activities at the store. This was confirmed by some beauty influencers who come and covered the activities on the opening day of the store at Senayan City. Many interesting promos were offered, such as creating a member card on that day and get a free gift of 1 set of products, for those whoshoppedatleastRp350.000.Starting that day, consumers and influencers have provided reviews and commented positively about Innisfree products, and encouraged friends to use Innisfree through social media, as a form of e-WOM. Then it becomes informants' and other consumers' intention to buy.

Innisfree customers are teenage girls of the millennial generation who are active users of social media. Innisfree is featured on social media as a product that gets a positive response, so it can provide knowledge to others who will buy cosmetic products. e-WOM about Innisfree has been happening positively in Indonesia such as Lazada.co.id, which discusses Innisfree as an eco-friendly beauty product, and is able to optimize health and skin freshness naturally [16].

In social media, Innisfree is discussed as cosmetics that rely on natural resources taken directly from Jeju Island, South Korea, such as green peas, volcanic pore cay, green tea, sea 
mustard \& gulfweed, tangerine, camellia, and nutmeg tree. They are believed to have efficacy. Through e-WOM, Innisfree stands out in its green campaign. Innisfree also solidifies its commitment to the use of eco- friendly containers and continues to support green life-themed campaigns such as eco-handkerchief, bottle recycling, and protecting the natural environment in Jeju [17].

The two images above belong to the Posted Review category. This includes consumers' opinions published on the Internet by sellers, sites that provide space for consumers' opinions or consumers that publish their opinions on their own blogs and Mailbags, including comments from consumers or readers and feedback published on the consumer product manufacturing organization's product sites, service providers, magazines, or news providers [10].

The brand process was successful. Take e-WOM on the Innisfree Indonesia's Facebook official account that mentions that Innisfree product is made from natural materials and environmentally friendly that is good not only for dry skin but also for all skin, can reduce excess oil and shrink the pores of the face.

The results of qualitative research and the study have shown how Innisfree brand awareness has been successful in Indonesia as indicated by the number of sales and the fact that e-WOM has been successfully conducted by Innisfree as an eco-friendly product.

\section{CONCLUSION}

Based on the above discussion, it can be concluded that Innisfree brand awareness of Indonesian women has been in accordance with the company's target, as shown by the increasing number of transactions and visitors to Innisfree's four outlets. Since famous Korean artists who became Innisfree's ambassadors in social media, such as actor Lee Min Ho and SNSD's Yoona, the brand awareness of Innisfree brand also supported by the rampant posts and reviews of beauty influencers through social media about Innisfree products cause the motivation tobuy.

Innisfree brand processing as eco-friendly product via e-WOM has been successfully created, shown by positive comment posts from the Innisfree Facebook followers, in the web and marketplace such as Lazada Indonesia. Also consumers encouraged friends to use Innisfree through social media, as a form of e-WOM. Then it becomes informants' and other consumers' intention to buy.

\section{REFERENCES}

[1] K. Goodrich and M. de Mooij, "How 'social' are social media? A cross-cultural comparison of online and offline purchase decision influences," J. Mark. Commun., vol. 20, no. 1-2, pp. 103-116, Mar. 2014.

[2] A. Cheema and A. M. Kaikati, "The Effect of Need for Uniqueness on Word of Mouth," J. Mark. Res., vol. 47, no. 3, pp. 553-563, Jun. 2010.

[3] J. Koponen, "Harnessing the impact of electronic word of mouth on purchase intention of cosmetic based on the functional attitude theory," Aalto University School of Business, 2017.

[4] L. M. Johri and K. Sahasakmontri, "Green marketing of cosmetics and toiletries in Thailand," J. Consum. Mark., vol. 15, no. 3, pp. 265-281, Jun. 1998.

[5] E. K. Macdonald and B. M. Sharp, "Brand Awareness Effects on Consumer Decision Making for a Common, Repeat Purchase Product:," J. Bus. Res., vol. 48, no. 1, pp. 5- 
15, Apr. 2000.

[6] A. Bhayani, "Word of mouth in consumers purchase decisions: The moderating role of product type," in 21st IAMB Conference, 2016, pp. 1-13.

[7] D. A. Aaker, "Measuring Brand Equity Across Products and Markets," Calif. Manage. Rev., vol. 38, no. 3, pp. 102-120, Apr. 1996.

[8] S. Hoeffler and K. L. Keller, "Building Brand Equity through Corporate Societal Marketing," J. Public Policy \{\&\} Mark., vol. 21, no. 1, pp. 78-89, Apr. 2002.

[9] P. Kotler, G. Armstrong, J. Saunders, and V. Wong, "Principles of Marketing," Corp. Commun. An Int. J., vol. 6, no. 3, pp. 164-165, Sep. 2001.

[10] K. A. Machleit, C. P. Haugtvedt, and Richard Yalch, Online consumer psychology: understanding and influencing consumer behavior in the virtual world. New Jersey: Psychology Press, 2005.

[11] N. Denzin and Y. Lincoln, Strategies of Qualitative Inquiry. Illinois: Sage Publication Inc, 2013.

[12] K. J. Preacher and A. F. Hayes, "SPSS and SAS procedures for estimating indirect effects in simple mediation models," Behav. Res. Methods, Instruments, Comput., vol. 36, no. 4, pp. 717-731, Nov. 2004.

[13] C. A. Setyanti, "Korea Selatan Pencetus Munculnya Era Skin Care Make-up," CNN Indonesia, 2018. .

[14] Nusabali, "Pertumbuhan Industri Kosmetik Pesat," Nusabali, 2018. .

[15] E. Pulanco, "Exploring The Korean Beauty Product Trend: Benefits Of Products, Reasons For Popularity," The Odyssey Online, 2018. .

[16] Lazada, "Innisfree," Lazada, 2018. .

[17] Beautynesia, "Iconic Beauty, 5 Negara Dengan Beauty Brands Terlegendaris," Beutynesia, 2018. [Online]. Available: http://beautynesia.id/6218. 